\title{
China-ASEAN Free Trade: Complementary or Competition
}

\author{
Nasrudin ${ }^{1}$, Bonar M.Sinaga ${ }^{1}$, Muhammad Firdaus ${ }^{1}$, Dedi Walujadi ${ }^{2}$ \\ ${ }^{\prime}$ (Faculty of Economics and Management, Bogor Agricultural University, Indonesia) \\ ${ }^{2}$ (BPS-Statistics Indonesia)
}

\begin{abstract}
Indonesia and ASEAN countries generally have relatively the same resource, mainly as a fellow producer of agricultural products. Joining Chinainto the regional economic integration through theagreement China-ASEAN Free Trade Area (CAFTA), giving new opportunities and challenges for them. The opportunities come from the openingof the large market of China whose many products are relatively different. But it is also a challenge because of the pressure of competition. Competition pressures come not only because of the influx of cheaper Chinese products, but also competition among ASEAN countries due to the similarity of their products. For example, Indonesia and Malaysia are the two largest palm oil exporters in the world, and Thailand (with Indonesia) is the world's major exporters of natural rubber. This paper aims to examine the trend of complementarity and similarity CAFTA countries and the correlation to exports trend. By using annual time series data 1995-2010, the analysis is based on the two main indicators; complementarity and export similarity index.
\end{abstract}

Keywords: complementarity, export similarity, regional economic integration

\section{INTRODUCTION}

Many ASEAN countries such as Indonesia, Malaysia, Thailand and Vietnam have the same resources, especially as a producer of agricultural products. ASEAN economic integration through the ASEAN Free Trade Area (AFTA) since 1993 did not increase the volume of trade substantially, because the products are relatively similar across countries (Vollrath, 1999). The some similarity of ASEAN countries such as in geographic, culture and proximity descent come they have more similar products than complement each other. The joining China into the single market gives a new color and expect enlarge the market. Trading volume is believed to be increasing due to differences in the products and culture between ASEAN and China. The similarity of the products poses competition among ASEAN countries. For example, Thailand is the largest producer of natural rubber in the world is also a mainstay Indonesian product. Similarly, both Indonesia and Malaysia are the biggest producers and exporter of palm oil in the world. As fellow producer of tropical agriculture, a competition among suppliers could reduce producer prices. On the other side, as among buyers (importers) of China's industrial products, it will raise the bargaining of Chinese products price. On the high similarity of ASEAN product, the economic integration of China-ASEAN should be considered more carefully.

China-ASEAN Free Trade Agreement (CAFTA) is a trade cooperation agreement as an initial stage toward regional economic integration of ASEAN and China. Integration in the free trade agreement (FTA) level is characterized by a reducing or removing the tariffof all goods and services. Each member is still free to make anagreement with other countries outside members. If deemed beneficial FTAs can be developed into a customunion. In the custom union, member states enact the same policy towards non-members. Not only the elimination of tariff and quota restrictions on imports between members, but also tariff agreements with countries outside members agreed/arranged by members. Even has emerged discourse towards ASEAN common market, through the ASEAN Economic Community in 2015, which not only liberation movement of goods and services, but also the movement of factors of production, capital and labor.

Nevertheless, the possibility of CAFTA continues to be a custom union depends on several factors: static and dynamic. Static factors are factors that can be directly compared between before and after the integration with nature is static, includes (Park et al, 2008): (1) size of the union or the size of the market, (2) the structure of the initial rates (before integration), both among members and outside members, (3) pre-integration level of intra-regional and extra-regional trade; (4) differences in the level of economic development, (5) geographical difficulties and transportation infrastructure; (6) substitutability of products, and (7) whether the members of the structure between complementary or competitive. While the dynamic factors are difficult to measure and it is not often detected (Park 2006; Park et al, 2008): (1) higher competition that improve efficiency, (2) gains of specialization, economies of scale, and learning-by-doing, (3) a decrease in intraregional transactions costs, (4) some protection from the world market, and (5) bargaining power one on one with the industrialized countries. Park (2006), Achsani (2008) and Park et al (2008) see the CAFTA has a positive pre-condition as static factors. CAFTA is a very large market potential, although geographically adjacent connective infrastructure is not as good as the European Union (because of the archipelagic territory), 
as well as the economic development level is relatively the same (except a Singapore). Substitutability of products in the sense but not the same kind between China and ASEAN, will improve the chances of trade creation. Tariff reduction is done gradually starting in 2004, is an attempt to harmonize the initial tariff structure as well as to condition prior to the member states to integrate further. However, there are other conditions that can affect the success of economic integration, namely whether the conditions between the member countries need each other as complementary or competing with each other because of the similarity of products.

Economic relations between China and ASEAN on the free trade would be a competition and partnership. To be able to move towards regional economic integration further, it is certainly important to know how the structure of trade between member countries. If the complementary more dominant, it would be easier towards higher levels of integration. Conversely, if the competition is more prominent, because their products are relatively the same, it needs a lot of adjustments first. To be comparable between countries, then both of these are described in two important indicators, namely complementarity index and export similarity index. This paper aims to predict the future prospects of CAFTA, with a focus on export complementarity and similarity. It is Interesting to explore about trade relations between members of CAFTA, complement or competitive? Is tariff reduction through the FTA makes member states are increasing in complementary or even more competitive? As well as the influence of complementary and competing against on intra-CAFTA exports.

\subsection{Complementarity and Trade Prospects}

\section{THEORETICAL BACKGROUND}

Relation on international trade is essentially complements, interdependent and beneficial to both parties. Similarly in the regional economic integration (FTA), specialization will occur when the higher-cost domestic product replaced by the lower-costof import products. In other words, the more efficient foreign producers replace inefficient domestic producers. Agrarian countries will export the agricultural products to industrial countries and vice versa industrial countries will export their products to the agrarian countries. May also occur in different industries such as exemplified by Park (2006), in the case of CAFTA, Thailand better import textiles from China, and vice versa China better import of automobiles from Thailand than producing himself. Unfortunately, in fact certain countries often import for almost all products and other state otherwise. Agricultural country as Indonesia, even they import agricultural products also produced domestically as rice, fruits, vegetables, and others. If one country tends to dominate, it is actually happening is not integration but economic exploitation.

To measure the level of complementarityamong FTA members, we use complementarity index. Complementarity index measures the degree of conformity patterns (supply) of a country's export pattern (demand) imports of other countries in a regional FTA. Complementarity index is formulated as follows (Plummer et al, 2010);

$I C_{n k r}=1-\frac{1}{2}\left\{\sum_{\partial} a b s\left[\left(M_{r k} / M_{r}\right)-\left(X_{n k} / X_{n}\right)\right]\right\}$

where:

$\mathrm{ICnkr}=$ index of complementarity year $\mathrm{n}$, commodity $\mathrm{k}$ in region $\mathrm{r}$

$\mathrm{Mk}=\mathrm{k}$ commodities imported by region $\mathrm{r}$

$\mathrm{Mr}=$ total imports of region $\mathrm{r}$

Xnk $=$ exports of commodity $\mathrm{k} n$ state

$\mathrm{Xn}=$ total exports of country $\mathrm{n} \mathrm{r}$

In the context of this study, $r$ is the CAFTA region

The value of complementarity index is ranges between 0 and 1 , where 0 indicates no overlap (no match at all) and 1 indicates perfect match in the pattern of export-import. The high degree of complementarity indicates a more promising prospect for success in trade through FTAs.High complementarity index for all members, showed conditions among member states that are complementary, mutually beneficial, which led to specialization. In such conditions, it is a prospective for further economic integration. If the high complementarity index for a particular country, while others are low, it can lead to domination by certain countries in regional trade. Meanwhile, if all low complementarity, intra-regional trade is also low, low interdependence and the regional economic integration is not prospective.

\subsection{Export Similarity and Competition Pressure}

ASEAN countries are generally agrarian, with similar tropical agricultural products. For example, both Indonesia and Thailand are exporter of natural rubber in the world. Similarly crude palm oil, as well as Malaysia, Indonesia is the largest producer and exporter in the world. There are many products similar fellow ASEAN, especially agricultural and food products such as rice, cassava, fruits, sugar and others. The similarity of these products causes the pressure of competition. If similar products abundant supply while demand remains, then the price of the product will decrease. When producers (exporter) are not able to perform the cost- 
efficiency, they will not compete and would be shut down. To obtain how big the pressure of competition experienced by the country's product in the FTA, export similarity index can be used.

Export similarity index illustrates the degree of similarity between the profiles of a country's exports to other countries in the region. Export similarity is formulated as follows (Plummer et al, 2010):

$I S_{n k r}=\sum_{\partial} \min \left[\left(X_{r k} / X_{r}\right),\left(X_{n k} / X_{n}\right)\right]$

where:

ESnkr $=$ index of export similarity year $\mathrm{n}$, for commodity $\mathrm{k}$ in region $\mathrm{r}$

Xrk = exports of commodity $\mathrm{k}$ by region $\mathrm{r}$

$\mathrm{Xr}=$ total exports of region $\mathrm{r}$

$\mathrm{Xnk}=$ exports of commodity $\mathrm{k} n$ state

$\mathrm{Xn}=$ total exports of country $\mathrm{n} \mathrm{r}$

In the context of this study, $r$ is the CAFTA region

The Export Similarity Index ranges between 0 and 1, where 0 indicates no overlap in the export profile (the state has no competitors in the region), while 1 indicates perfect overlap. The more similarities in the export profile, shows the limitations of the potential benefits (gains) of inter-industry trade in regional trade agreements. The higher index of export similarity shown it more competitors and then potential benefits of FTA more limited. Plummer et al (2010) notes that the index could not describe the potential gains obtained from intra-industry trade.

\section{VARIABLE SELECTION AND DATA AgGREgation}

After the economic crises (1997-1998) that hit several ASEAN countries, the dynamics of ASEAN trade can be divided into two periods; before and after CAFTA. Although CAFTA has been agreed since 2002, but its implementation is done in stages introduce in 2004. The releasing price has not yet for all commodities until now.However, it is interesting to research how the chanceof opportunities/benefits to be gained, as well as competitive pressures faced. To see the possibility after the implementation of CAFTA, the export similarity andcomplementarity index differentiated according to the time before and after CAFTA. The index before CAFTA is calculated from the average of the 1999-2004 indices, while the index after CAFTA was calculated from the average of the 2005-2010 indices. Because the most of the ASEAN countries is agricultural, then the calculation is differentiated according to product group categories; foods commodity (all foods item), non-food agriculture (agriculture raw materials) and non-agricultural commodities.

The food commodities refers to UNCTAD data that is products those are covered in chapter $0,1,22$ and 4 of Standard International of Trade Classification (SITC) Revision 4, as follows: (00) Live animals; (01) Meat and meat preparations; (02) Dairy products and birds' eggs; (03) Fish, crustaceans, molluscs and preparations; (04) Cereals and cereal preparations; (05) Vegetables and fruits; (06) Sugar, sugar preparations and honey; (07) Coffee, tea, cocoa, spices; (08) Feedstuff for animals; (11) Beverages; (12) Tobacco and tobacco manufactures; (22) Oil seeds and oleaginous fruits; (41) Animal oils and fats; (41) Fixed vegetable oils and fats; and (43) Processed Animal and vegetable oils and fats. While non-food agricultural commodities or raw materials derived from agriculture raw material are all products included in Chapter 2 SITC other 22, 27 and 28, namely; (21) Hides, skins and furskins; (23) Crude rubber; (24) Cork and wood; (25) Pulp and waste paper; (26) Textiles fibres and their wastes; and (29) Crude animal and vegetable materials.

\subsection{The Structure of Intra-CAFTA Trade}

\section{RESUlT AND DiscuSSION}

China is an important trading partner for ASEAN. On the average over 2005-2010 years, China is 9.5 percent of ASEAN exports and 8.9 percent of Indonesia's export markets. In the same time, respectively China is 12.6 percent and 12.9 percent of imports origin ASEAN and Indonesia (Table 1). In terms of China, ASEAN is not an important trading partner when viewed from the share of their trade. For China, Indonesia only 1.18 percent and ASEAN 6.92 percent of export market them. Although the figure is much higher than before the CAFTA, but still relatively low. While more than half of China's imports come from the newly industrialized countries (NICs) and Japan (Tambunan, 2005). Share of trade between ASEAN and China did increase after the implementation of CAFTA. However, the increase in imports of ASEAN (including Indonesia) from China is higher than their exports to China. Indonesia's trade deficit from China and ASEAN tends to increase. The trade deficit of Indonesia and ASEAN from China in the average of 1999-2004 years (before CAFTA), respectively US $\$ 0.6$ billion and US\$ 0.5 billion, the years 2005-2010 (after CAFTA ) increase to US\$ 3.5 billion and US\$ 12.2 billion. 
China-ASEAN Free Trade: Complementary or Competition

Table 1 Matrix for Indonesia, ASEAN and China Trade Before-After CAFTA (in Billion US\$)

\begin{tabular}{|c|c|c|c|c|c|c|c|c|c|c|c|}
\hline \multirow[b]{2}{*}{ Country } & \multirow[b]{2}{*}{ Product } & \multicolumn{2}{|c|}{ Indonesia } & \multicolumn{2}{|c|}{ ASEAN } & \multicolumn{2}{|c|}{ China } & \multicolumn{2}{|c|}{ ROW } & \multicolumn{2}{|c|}{ World } \\
\hline & & $\begin{array}{c}1999- \\
2004\end{array}$ & $\begin{array}{c}2005- \\
2010\end{array}$ & $\begin{array}{c}1999- \\
2004\end{array}$ & $\begin{array}{l}2005- \\
2010\end{array}$ & $\begin{array}{l}1999- \\
2004\end{array}$ & $\begin{array}{c}2005- \\
2010\end{array}$ & $\begin{array}{c}1999- \\
2004\end{array}$ & $\begin{array}{c}2005- \\
2010\end{array}$ & $\begin{array}{c}1999- \\
2004\end{array}$ & $\begin{array}{c}2005- \\
2010\end{array}$ \\
\hline (1) & (2) & (3) & (4) & (5) & (6) & (7) & (8) & (9) & (10) & (11) & (12) \\
\hline \multirow[t]{4}{*}{ Indonesia } & Total & 0.0 & 0.0 & 10.4 & 23.6 & 3.0 & 10.6 & 46.1 & 84.4 & 59.5 & 118.6 \\
\hline & All Foods & 0.0 & 0.0 & 1.2 & 3.4 & 0.4 & 1.8 & 4.9 & 12.8 & 6.4 & 18.0 \\
\hline & Raw Agri & 0.0 & 0.0 & 0.2 & 0.5 & 0.5 & 1.5 & 1.9 & 5.1 & 2.5 & 7.0 \\
\hline & Others & 0.0 & 0.0 & 9.0 & 19.7 & 2.2 & 7.3 & 39.3 & 66.6 & 50.5 & 93.6 \\
\hline \multirow{4}{*}{ ASEAN } & Total & 10.1 & 41.3 & 81.4 & 149.5 & 20.1 & 70.0 & 265.0 & 475.8 & 376.8 & 736.5 \\
\hline & All Foods & 0.9 & 1.8 & 4.6 & 9.5 & 1.7 & 5.1 & 20.5 & 39.8 & 27.6 & 56.3 \\
\hline & Raw Agri & 0.1 & 0.3 & 1.1 & 2.5 & 1.3 & 4.7 & 4.6 & 8.4 & 7.1 & 15.8 \\
\hline & Others & 9.1 & 39.2 & 75.7 & 137.5 & 17.2 & 60.2 & 240.0 & 427.6 & 342.0 & 664.4 \\
\hline \multirow[t]{4}{*}{ China } & Total & 3.6 & 14.1 & 20.6 & 82.6 & 0.0 & 0.0 & 320.3 & $1,096.8$ & 344.6 & $1,193.5$ \\
\hline & All Foods & 0.4 & 0.9 & 1.2 & 3.2 & 0.0 & 0.0 & 14.4 & 29.4 & 16.0 & 33.5 \\
\hline & Raw Agri & 0.1 & 0.1 & 0.1 & 0.4 & 0.0 & 0.0 & 2.6 & 5.2 & 2.8 & 5.6 \\
\hline & Others & 3.2 & 13.1 & 19.2 & 79.0 & 0.0 & 0.0 & 303.4 & $1,062.2$ & 325.8 & $1,154.4$ \\
\hline \multirow[t]{4}{*}{ ROW } & Total & 27.7 & 53.7 & 222.4 & 400.6 & 268.3 & 815.4 & $5,417.8$ & $9,690.1$ & $5,936.2$ & $10,959.9$ \\
\hline & All Foods & 2.1 & 5.1 & 9.3 & 19.5 & 9.6 & 29.0 & 411.0 & 746.0 & 432.0 & 799.5 \\
\hline & Raw Agri & 1.8 & 2.6 & 2.5 & 4.8 & 9.8 & 26.5 & 93.3 & 126.5 & 107.5 & 160.4 \\
\hline & Others & 23.8 & 46.0 & 210.6 & 376.3 & 248.9 & 759.9 & $4,913.5$ & $8,817.7$ & $5,396.8$ & $9,999.9$ \\
\hline \multirow[t]{4}{*}{ World } & Total & 41.5 & 109.1 & 334.8 & 656.3 & 291.5 & 896.0 & $6,049.3$ & $11,347.2$ & $6,717.0$ & $13,008.6$ \\
\hline & All Foods & 3.4 & 7.7 & 16.3 & 35.6 & 11.7 & 36.0 & 450.6 & 828.0 & 482.0 & 907.3 \\
\hline & Raw Agri & 2.0 & 3.0 & 3.9 & 8.1 & 11.6 & 32.7 & 102.4 & 145.1 & 119.8 & 189.0 \\
\hline & Others & 36.2 & 98.4 & 314.6 & 612.5 & 268.2 & 827.3 & $5,496.3$ & $10,374.1$ & $6,115.2$ & $11,912.3$ \\
\hline
\end{tabular}

Source: UNCTADStat, available at http:/www.unctad.org [1st August 2012]

Description: - The numberlistedin the tableareaverageannual

- ASEAN:All ASEANcountries, except Indonesia; ROW: rest of the world

One indication of the success of regional economic integration is a fellow member of the increase in trade (trade creation). In general there has been an increase in exports of member countries to meet the demand for fellow members of CAFTA. Contribution of member countries' exports in 1999-2004 amounted to 21.9 percent, to 23.2 percent in 2005-2010 (Table 2). This fact is known by Tambunan (2005) there is no guarantee that the CAFTA will have a positive impact for ASEAN, including Indonesia. ASEAN is China's market expansion that began after the saturated economic growth and exports are very fast in the last two decades (Lijun, 2003).Judging from these indicators, China is dominant with an increase in the highest contribution, followed by Vietnam and Thailand. Their market penetration is mainly for non-agricultural and foods products. China's top products include machinery and parts, electronics, telecommunications, toys and textiles, in addition to vegetables and fruits for food products. Thailand and Vietnam have increased primarily on agricultural raw materials, such as natural rubber and wood. While Indonesia has increase in the food products from the plantation subsector such as crude palm oil, coffee, tea and cacao. Even though Indonesia, Thailand and Vietnam also exporters of non-agricultural products such as oil and gas (gas, coal), textiles and electronics.

China's trade share in the CAFTA experienced the highest increase compared to other members (Table 2). The increase occurred even for all product categories studied. This means that the dynamics of regional trade tends to lead to the "China threat to ASEAN" which predicted by Tambunan (2005), or competitive pressure for ASEAN (Tongzon, 2005). In further detail, the share of ASEAN exports increased for the category of non-food agricultural products (agricultural raw materials), especially Thailand. This matches previous allegations that China's motivation in CAFTA is to obtain raw materials in sustaining their economic growth consistency (Lijun, 2003). While the increase in the share of Chinese exports, especially in the category of non-agricultural products (manufacturing). At least there are two things that allegedly led to this: first, China's export structure has much in common with the ASEAN economies (Tongzon, 2005). China's top export industry which is 84 percent of total export is also a major export industry of ASEAN. Second, it's due to the comparative advantage of China's unit labor-cost (Roland-Holst and Weiss, 2004; Tambunan, 2005).

Table 2 shown for a food category, Malaysia is the largest supplier of food demand CAFTA. Although its share declined, but still remain the highest. Indonesia and China show prospective trend in the category. China has prospective for fruits and other horticulture, as well as food products industry. Exports of Indonesian food product categories are quite promising, which increased the share visible. But it must be careful to address this result, because the food category in this paper is "all the ingredients and food products". Indonesia still rely on plantation product, such as palm, cocoa, coffee, tea and natural rubber. Generally, ASEAN countries came under pressure with the joining of China. Their food products compete with China's fruits, horticulture and other industrial foods products. In other side, they are also competes each other, i.e. Malaysia competes with Indonesian plantations, Thailand basic foods competes with Vietnam and Philippines, etc. 
China-ASEAN Free Trade: Complementary or Competition

Table 2 Contribution of Countries Exports to Meet a CAFTA Demand, Before and After CAFTA

\begin{tabular}{|c|c|c|c|c|c|c|c|c|c|c|c|}
\hline \multicolumn{2}{|c|}{ Ranking } & \multirow[t]{2}{*}{ Country } & \multicolumn{3}{|c|}{$\begin{array}{l}\text { Export to CAFTA / total } \\
\text { import CAFTA }(\%)\end{array}$} & \multicolumn{2}{|c|}{ Ranking } & \multirow[t]{2}{*}{ Country } & \multicolumn{3}{|c|}{$\begin{array}{l}\text { Export to CAFTA / total } \\
\text { import CAFTA }(\%)\end{array}$} \\
\hline Pre & Post & & Pre & Pre & Post & Pre & Post & & Pre & Post & change \\
\hline (1) & (2) & (3) & (4) & (5) & (6) & $(7)$ & $(8)$ & $(9)$ & $(10)$ & $(11)$ & (12) \\
\hline \multicolumn{6}{|c|}{ Total Products } & \multicolumn{6}{|c|}{ Non-Agricultural } \\
\hline 1 & 1 & Singapore & 7.288 & 7.059 & -0.229 & 1 & 1 & Singapore & 7.609 & 7.427 & -0.181 \\
\hline 3 & 2 & China & 3.626 & 5.813 & 2.186 & 3 & 2 & China & 3.624 & 5.985 & 2.360 \\
\hline 2 & 3 & Malaysia & 4.420 & 3.521 & -0.899 & 2 & 3 & Malaysia & 4.279 & 3.319 & -0.960 \\
\hline 4 & 4 & Thailand & 2.721 & 2.899 & 0.178 & 4 & 4 & Thailand & 2.435 & 2.613 & 0.179 \\
\hline 5 & 5 & Indonesia & 2.008 & 2.059 & 0.051 & 5 & 5 & Indonesia & 1.810 & 1.754 & -0.056 \\
\hline 6 & 6 & Philippines & 1.076 & 0.767 & -0.309 & 6 & 6 & Philippines & 1.111 & 0.790 & -0.321 \\
\hline 7 & 7 & Vietnam & 0.442 & 0.698 & 0.255 & 7 & 7 & Vietnam & 0.324 & 0.541 & 0.216 \\
\hline 8 & 8 & Myanmar & 0.139 & 0.212 & 0.073 & 9 & 8 & Myanmar & 0.094 & 0.168 & 0.074 \\
\hline 9 & 9 & Brunei & 0.131 & 0.122 & -0.009 & 8 & 9 & Brunei & 0.141 & 0.131 & -0.010 \\
\hline 11 & 10 & Laos & 0.025 & 0.046 & 0.021 & 11 & 10 & Laos & 0.009 & 0.036 & 0.027 \\
\hline 10 & 11 & Cambodia & 0.026 & 0.027 & 0.001 & 10 & 11 & Cambodia & 0.015 & 0.016 & 0.001 \\
\hline \multicolumn{3}{|c|}{ CAFTA } & 21.902 & 23.221 & 1.320 & \multicolumn{3}{|c|}{ CAFTA } & 21.451 & 22.780 & 1.330 \\
\hline \multicolumn{6}{|c|}{ All Foods } & \multicolumn{6}{|c|}{ Agricultural Raw Materials } \\
\hline 1 & 1 & Malaysia & 7.727 & 7.558 & -0.169 & 1 & 1 & Thailand & 6.121 & 8.049 & 1.928 \\
\hline 4 & 2 & Indonesia & 4.944 & 6.629 & 1.685 & 2 & 2 & Indonesia & 3.742 & 4.459 & 0.717 \\
\hline 2 & 3 & Thailand & 6.479 & 5.572 & -0.907 & 3 & 3 & Malaysia & 3.494 & 3.303 & -0.191 \\
\hline 3 & 4 & China & 5.114 & 5.121 & 0.007 & 7 & 4 & Vietnam & 0.802 & 2.444 & 1.642 \\
\hline 5 & 5 & Singapore & 4.280 & 3.321 & -0.960 & 5 & 5 & Myanmar & 1.208 & 1.350 & 0.142 \\
\hline 6 & 6 & Vietnam & 2.572 & 2.771 & 0.199 & 6 & 6 & China & 1.024 & 1.060 & 0.036 \\
\hline 7 & 7 & Philippines & 0.879 & 0.646 & -0.232 & 4 & 7 & Singapore & 1.307 & 0.929 & -0.378 \\
\hline 8 & 8 & Myanmar & 0.434 & 0.428 & -0.006 & 8 & 8 & Laos & 0.582 & 0.377 & -0.205 \\
\hline 9 & 9 & Cambodia & 0.046 & 0.085 & 0.040 & 9 & 9 & Cambodia & 0.389 & 0.299 & -0.090 \\
\hline 10 & 10 & Laos & 0.032 & 0.055 & 0.022 & 10 & 10 & Philippines & 0.170 & 0.160 & -0.010 \\
\hline 11 & 11 & Brunei & 0.003 & 0.006 & 0.003 & 11 & 11 & Brunei & 0.004 & 0.010 & 0.006 \\
\hline \multicolumn{3}{|c|}{ CAFTA } & 32.511 & 32.193 & -0.318 & \multicolumn{3}{|c|}{ CAFTA } & 18.844 & 22.439 & 3.595 \\
\hline
\end{tabular}

Source: UNCTADStat (processed)

Description: pre-CAFTA = 1999-2004 year; CAFTA = 2005-2010 year

In the agricultural raw materials category, Indonesia competes with Thailand and the rising Vietnam. It's caused of their similar products, particularly rubber and wood which the main export destination to China (for CAFTA). In this case, Thailand is predicted to win the competition, evident from the highest and positive trend of intra-CAFTA export share. Thailand, Indonesia and Vietnam export are expected to increase along with the raw material needs china. Malaysia seems to be losing the regional market, although exports are still high. In the non-agricultural product, China's prospective for the toy industry, electronics and spare parts. Thailand increased in plastics and electronics industry. Singapore as a trading country still holds the highest share (Table 2), but the joining China pressured them because the substituted product. While the share of Indonesia is still low, not much role in this category, so the value of the IC and IS low too.

\subsection{Complementary and Export Similarity among Countries}

The value of complementarity index closes to 1 means country's exports in accordance with import demand. On average, ASEAN-5 and China have the potential to succeed in the economic integration of CAFTA. In this case of Malaysia,Thailand, China and Philippines were the countries which the great potency, because of their complementarity index is high. In the course of CAFTA, almost all countries have increased complementarity index, namely Malaysia, China, Philippines, Vietnam and Cambodia (Table 3). Indonesia is in the opposite position (decreased) with Laos and Brunei, means that Indonesia has not been able to optimize its resources to compete in entering the ASEAN-China market is very large.Judging fromthe annualtrend, Vietnam showed significant increasing trend of this country's role in the regional trade. Conversely Indonesia's role in intra-CAFTA trade tends to decline.

The similarity of Indonesian products to neighboring countries, with relatively the same market, it will bring the pressure of competition. The pressure of competition should create new innovations (in order to win the competition), but the effect in the short-term is declining in the price or decreasing the level of exports. The similarity of a country's export products to other countries in economic integration are reflected in indicators of export similarity index. Both indicators are shown in Tables 3.Export similarity index value close to 1 means that the country's exports are similar to other exporting countries of CAFTA. China has the highest index value and is likely to increase, meaning that the Chinese products are exported to regional markets have much in common with the ASEAN exported products. The implication is that the implementation of CAFTA add new competitor for ASEAN. Two possibilities would be happen; (1) share of Chinese exports would increase when they win in the competition, or (2) more difficult for China to entry into the ASEAN market because the product is similar. Although China's similarity was increase, but their export's share were still highly increased. Base on the fact, the second possibilities might be happen. But keep in mind that the numbers in Tables 3 are for the total 
product, which shows the inter-industry trade or inter-sector. In that inter-industry trade, Indonesia is relatively low similarity, has a great opportunity to increase regional trade. Decreasing similarity may indicate specialization. However, if the specialization is as an exporter of raw materials, the added value is not great. To find outmore in depth, then the similarity is distinguished by several commodity groups.

Table4 Complementarity and ExportSimilarity Index of CAFTAMembers: Trend Comparison, 2000-2010

\begin{tabular}{|c|c|c|c|c|c|c|c|c|c|c|c|c|}
\hline \multirow{2}{*}{ Negara } & \multicolumn{6}{|c|}{ Complementarity } & \multicolumn{6}{|c|}{ Similarity } \\
\hline & 2000 & 2002 & 2004 & 2006 & 2008 & 2010 & 2000 & 2002 & 2004 & 2006 & 2008 & 2010 \\
\hline (1) & $(2)$ & (3) & (4) & $(5)$ & $(6)$ & (7) & $(8)$ & (9) & (10) & (11) & (12) & (13) \\
\hline Malaysia & 0.56 & 0.56 & 0.56 & 0.56 & 0.57 & 0.57 & 0.45 & 0.42 & 0.42 & 0.37 & 0.38 & 0.45 \\
\hline Thailand & 0.56 & 0.56 & 0.56 & 0.56 & 0.56 & 0.56 & 0.50 & 0.50 & 0.48 & 0.46 & 0.42 & 0.40 \\
\hline China & 0.53 & 0.54 & 0.54 & 0.55 & 0.56 & 0.56 & 0.49 & 0.51 & 0.50 & 0.55 & 0.58 & 0.56 \\
\hline Philippines & 0.53 & 0.54 & 0.54 & 0.54 & 0.55 & 0.56 & 0.38 & 0.42 & 0.42 & 0.49 & 0.46 & 0.49 \\
\hline Singapore & 0.54 & 0.55 & 0.55 & 0.54 & 0.54 & 0.54 & 0.54 & 0.50 & 0.44 & 0.41 & 0.51 & 0.44 \\
\hline Indonesia & 0.56 & 0.55 & 0.54 & 0.52 & 0.52 & 0.50 & 0.37 & 0.35 & 0.33 & 0.31 & 0.32 & 0.31 \\
\hline Vietnam & 0.41 & 0.41 & 0.42 & 0.44 & 0.52 & 0.49 & 0.26 & 0.27 & 0.27 & 0.27 & 0.32 & 0.32 \\
\hline Cambodia & 0.41 & 0.43 & 0.45 & 0.46 & 0.47 & 0.46 & 0.15 & 0.14 & 0.15 & 0.14 & 0.14 & 0.16 \\
\hline Myanmar & 0.45 & 0.44 & 0.45 & 0.45 & 0.46 & 0.46 & 0.20 & 0.24 & 0.17 & 0.20 & 0.21 & 0.20 \\
\hline Laos & 0.43 & 0.43 & 0.44 & 0.41 & 0.45 & 0.41 & 0.14 & 0.16 & 0.21 & 0.16 & 0.19 & 0.16 \\
\hline Brunei & 0.39 & 0.36 & 0.34 & 0.32 & 0.40 & 0.37 & 0.07 & 0.06 & 0.06 & 0.06 & 0.07 & 0.06 \\
\hline
\end{tabular}

Source: calculate from UNCTADStat

\subsection{Potential Gains and Competition Pressure}

Potential gains and competitive pressures in the regional economic integration can be measured by a combination of complementarity index (IC) and the export similarity index (IS). The combination of these two indicators can be displayed in ascatter plot X-Y, e.g. complementarity on the $\mathrm{Y}$ axis (vertical) and export similarity on the $\mathrm{X}$ axis (horizontal). The country's position on the plotting illustratesa theoretical indication, which in fact could be the opposite, i.e. potential but the fact of export share is decline. The difference with the fact to the theoretical predictions may happen, does not mean it is not important indicator. If it combined with other indicators (i.e. share of exports), it will helpful in solving the problem.
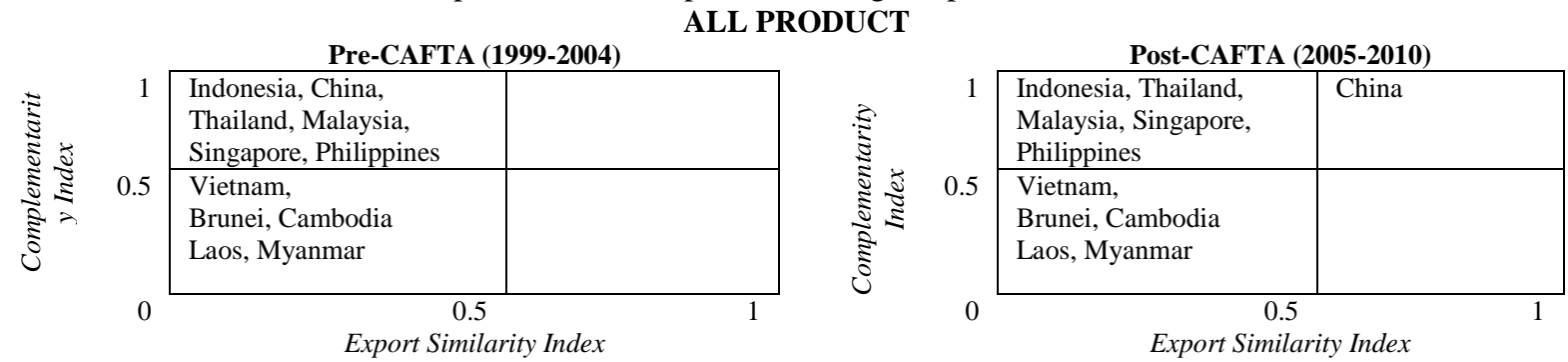

Figure 3 Matrices of Complementarity and Export Similarity Index for Before and After CAFTA

By plotting these data, the position of each country can be grouped into four quadrants according to the value of the IC and IS owned. Quadrant I (high IC and IS), depicts a country that has a strong potential with high competition. Despite many similar producers as competitors, butstill much demand. Quadrant II (low IC, IS high), indicating the state has a low profit potential by strong competition pressure. Countries in this condition need to work hardly to win the competition among members of regional economic integration. Quadrant III (low IC, IS low), indicating the state has the potential advantage of low competition with low pressure. Those products do not comply with the demands of the regional market, possibly neighbors countries are also not interested in developing it. They should outward orientation of regional or conduct further proceedings. Quadrant IV (high IC, IS low), indicating the country has the potential for high returns with low competition pressure. It is the country's flagship product. In this case, the countries more easier to penetrate into CAFTA's market.

\begin{tabular}{l}
\multicolumn{2}{c}{ Commodity: All Foods } \\
\multicolumn{1}{c|}{ Pre-CAFTA (1999-2004) } \\
\cline { 3 - 7 }
\end{tabular}




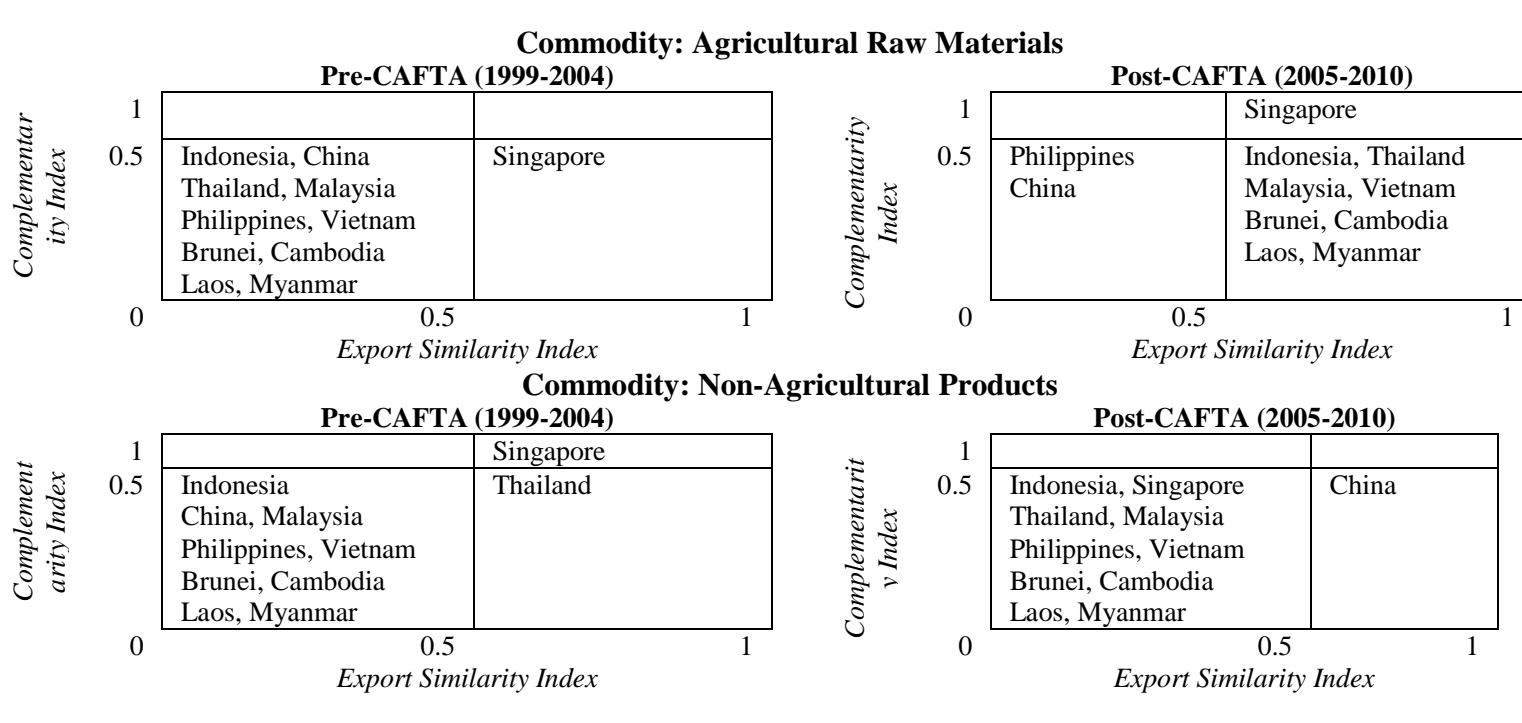

Figure 4 Complementarity Index (IC) and Export Similarity Index (IS) Before-After CAFTA, by Group of Commodities

From Figure 3, it can be presumed the implementation of the FTA to the entire product, prospective to be developed. Raw material will flow from ASEAN to China, while non-agricultural (manufactured products) flowing from China into ASEAN. If applied partially (Figure 4), for example, only for non-food category, it is not prospective because their similarity increased. For agricultural raw material category, export similarity index in most of the country has increased. They are mainly producers of agricultural products such as Indonesia, Thailand, Malaysia and Vietnam. It indicates that the implementation of CAFTA encourage ASEAN countries are generally agrarian will compete to export their agriculture raw material. The decrease/elimination of tariffs makes exporters to think quickly gain profit by push selling raw materials. However, it causes the competition pressure among ASEAN countries. These findings did not differ from Wai-Heng (2009) which saw the trend of an annual series that the degree of similarity between the net exports East Asian countries (including ASEAN), tends to increase.

\subsection{Correlation to Regional Export Share}

The correlation of complementarity index and similarity index with intra-CAFTA export is shown at Table 4 below. The complementarity index is positive correlation hypothetically with intra-CAFTA export, while the similarity index is negative correlation. Table 4 shown that the Indonesian exports have a positive correlation with the complementarity index, while a negative correlation with the similarity index. It's mean that the increasing in Indonesian exports depends on increased demand trading partner (complementary) and reduced their competitor (similarity). In short, only sold if needed, and could not sell as many rivals. If it continues, then it will lose the suspected Indonesian market in the region. When the export still depend on complementarity and similarity before, it will be difficult to grow in the performance of the next trade.

Table 4 Correlation of Complementarity and Export Similarity with Intra-CAFTA Export Share, Selected CAFTA Countries by Category, 1995-2010

\begin{tabular}{|c|c|c|c|c|c|c|c|}
\hline \multirow[t]{2}{*}{ Country } & \multirow[t]{2}{*}{ Group of commodities } & \multicolumn{4}{|c|}{$\begin{array}{c}\text { Coef of correlation between 'export } \\
\text { share to CAFTA' and }\end{array}$} & \multicolumn{2}{|c|}{$\begin{array}{c}\text { Intra CAFTA's export } \\
\text { performance }\end{array}$} \\
\hline & & Complementa & & Similarity & & Trend $^{1)}$ & Contribution $^{2)}$ \\
\hline (1) & (2) & (3) & & (4) & & (5) & $(6)$ \\
\hline \multirow[t]{3}{*}{ Indonesia } & All foods items & -0.04 & & -0.51 & $*$ & $(+)$ & high \\
\hline & Agricultural raw material & 0.73 & $* *$ & 0.21 & & $(+)$ & high \\
\hline & non-agricultural product & 0.88 & $* *$ & -0.78 & $* *$ & $(-)$ & low \\
\hline \multirow[t]{3}{*}{ China } & All foods items & 0.48 & $*$ & -0.64 & *** & $(+)$ & high \\
\hline & Agricultural raw material & 0.00 & & 0.37 & & $(+)$ & low \\
\hline & non-agricultural product & 0.68 & $* *$ & 0.84 & $* *$ & $(+)$ & high \\
\hline \multirow[t]{3}{*}{ Malaysia } & All foods items & 0.43 & $*$ & 0.32 & & $(-)$ & high \\
\hline & Agricultural raw material & 0.88 & $* *$ & 0.73 & $* *$ & $(-)$ & high \\
\hline & non-agricultural product & 0.85 & $* *$ & 0.01 & & $(-)$ & high \\
\hline \multirow[t]{3}{*}{ Philippines } & All foods items & -0.04 & & -0.47 & $*$ & $(-)$ & low \\
\hline & Agricultural raw material & 0.75 & $* *$ & 0.39 & & $(-)$ & low \\
\hline & non-agricultural product & 0.87 & $* *$ & 0.82 & $* *$ & $(-)$ & low \\
\hline \multirow[t]{3}{*}{ Thailand } & All foods items & -0.41 & & -0.77 & $* *$ & $(-)$ & high \\
\hline & Agricultural raw material & 0.67 & $* *$ & 0.63 & $* *$ & $(+)$ & high \\
\hline & non-agricultural product & -0.62 & $* *$ & -0.80 & $* *$ & $(+)$ & high \\
\hline
\end{tabular}


China-ASEAN Free Trade: Complementary or Competition

\begin{tabular}{llrrrrr}
\hline Vietnam & All foods items & -0.14 & -0.65 & $* *$ & $(+)$ & \multicolumn{1}{c}{ low } \\
& Agricultural raw material & 0.24 & 0.26 & & $(+)$ & high \\
& non-agricultural product & -0.11 & -0.23 & & $(+)$ & low \\
\hline
\end{tabular}

Source: author's calculation from UNCTADStat data

Description:

** statistically significant at $\alpha=1 \%$

* statistically significant at $\alpha=10 \%$

${ }^{1)}(+)$ if export share to CAFTA, after CAFTA>before CAFTA, and (-) if otherwise

${ }^{2}$ ) 'high' if intra CAFTA export contribution after CAFTA is greater than country member average share, and 'low' if otherwise

Complementarity is generally positively correlated with export share. Means that the increase in export share in line with the increase in complementarity. Only different thing is indicated by the non-agriculture product of Philippines, but its contribution in intra-CAFTA trade is relatively low. Unlike in theory, to agricultural raw materials, similarity is positively correlated with the share of export. This suggests that although many rivals but remain a mainstay. The risk is a low price may be, but Table 4 does not able to show the decreasing. The other possibilities are although similar but there is difference i.e. diversification product, postharvest management, etc. In this case, Thailand is predicted to win the competition, evident from the correlation between the intra-CAFTA export share and similarity index is positive and significant, high contribution and positive trend in intra-CAFTA trade.

For non-agricultural products, general similarity is negatively correlated with the share of exports. Special case is China's non-agriculture products. Despite thesimilarityincreased(Fig. 4), but share of exports increased sharply(Table 2). This indicates that the penetration of China into the ASEAN market is the main nonagricultural products (industrial).CAFTA not only increase competition among ASEAN countries in agricultural products (mainly raw material), but also gamble with non-agricultural products of China. The similarity of the products featured member states will hamper the process of economic integration. Such constraints arise because there is no increase in large trade (Vollrath, 1999; Riduan, 2009), as well as the possibility of competition between members of the market share. One of the most important parts in the study of CAFTA is the competitive pressure ASEAN countries by China. Tongzon (2005) found that China's export structure has much in common with the ASEAN economies. He calculates that China's export industry is the top 84 per cent of total exports, is also a major export industry of ASEAN. By a relative advantage in the unit labor cost, Roland-Holst and Weiss (2004) estimates that ASEAN will lose a substantial share of exports by China.

FTAs will be successful if the product is required (complement) by partners (members) and a substitution from the non-members products. As an illustration, both Malaysia (member) and USA (nonmembers) are producers of chicken meats. Indonesia should fortunate, because they can import chicken meat from Malaysia. Malaysia is also fortunate because the uranium be more salable. Other illustrations, both Indonesia (member) and Thailand (members) are producers of natural rubber. China's lucky to be able to import and choose a cheaper and good rubber, while Thailand and Indonesia to compete. FTAs should continue to be a custom union, when among member countries in need and complement each other, not the exploitation of one state against another. Lijun (2003) saw in the last two decades, China's exports grew very rapidly, and they have started congestion due to market saturation. With the increase in production capacity well above domestic needs, China should intensify search for new markets for export. The main target is the developing countries, where Chinese products have advantages in terms of low prices and a decent quality (competitive price and reasonable quality) than the price of an expensive product from the developed countries. In terms of imports, China needs raw materials from them. That makes China's interest to free trade with ASEAN. In contrast, because of their products are relatively similar, the orientation of ASEAN countries penetrate the Chinese market requires hard work to win the competition each other. If that's the case, then the FTAs only in favor of one party alone and less likely to be upgraded to the next level of regional economic integration.

\section{CONClusion}

CAFTA provides opportunities and challenges for ASEAN countries, including Indonesia. Interindustry trade of ASEAN-China is predicted to increase, but it raises some new concerns. There is a competition among ASEAN countries, especially Indonesia, Thailand and Malaysia for agricultural raw material product categories. The CAFTA further tighten the competition among ASEAN, especially coupled with the increase in Vietnam. There was also a competition between ASEAN countries and China to the category of non-agricultural products (especially manufacturing).

The increasing in Indonesian exports depends on increased demand trading partner (complementary) and reduced their competitor (similarity). This is presumably due to the lack of diversification of product innovation and quality improvement compared to competitors in an effort to win the competition. In short, only sold if needed, and do not sell as many rivals. If it continues, then it will lose the suspected Indonesian market in the region. The demand of partner countries is dynamic, so the products are sell well at the moment, in the future can be no longer in demand. In addition, post-implementation of CAFTA, the trend of export similarity tends to increase, which means the competition will be intense. Other ASEAN members had a big role in the 
CAFTA trade, generally also still depends on the similarity and complementarity. If exports still depend on complementarity and similarity before, it will be difficult to grow in the development of the next trade.

The high pressure is not always lower the export competition, if offset by an increase in the quality and efficiency to win the competition. It's evidenced by China, despite a high export similarity, but their export share in the regional market remains upward. Levels of higher economic integration will be easily achieved when export complementarity between members, as well as lower competition between members. The data showed export similarity of main products remains high and tends to increase after the CAFTA implementation. Therefore, for now custom union is still not recommended.

\section{REFERENCES}

[1] Vollrath, T. L, RTA's and Agricultural Trade: A Retrospective Assessment. (Chapter 2 in Burfisher, M.E. and E.A. Jones (Eds.) Regional Trade Agreements and U.S. Agriculture.Agricultural Economic Report No. 771. Economic Research Services, U.S. Department of Agriculture, Washington DC, 1999)

[2] Park, D., The Prospects of ASEAN-China Free Trade Area (ACFTA): A Quality Assessment. Nanyang Technological University, Singapore, 2006

[3] Park, D., I. Park, G.E.B. Estrada, Prospects of an ASEAN-People's Republic of China Free Trade Area: A Qualitative and Quantitative Analysis. ADB Working Series Paper No. 130 / October, 2008.

[4] Achsani, N. A., Economic Integration ASEAN+3: Opportunities and Chalanges. Indonesia Institute for Public Policy and Development Studies, Jakarta, 2008.(in Bahasa Indonesia)

[5] Riduan, Impact of Economic Integration on Investment in ASEAN Region: An Integration Model Analysis. Jurnal Organisasi dan Manajemen, 5(2), 2009, 95-107(in Bahasa Indonesia)

[6] Lijun, S, China-ASEAN Free Trade Area: Origin, Developments and Strategic Motivations. ISEAS Working Paper: International Politics and Security Issues Series No. 1. Institute of Southeast Asian Studies, Singapore, 2003

[7] Plummer, M.G., D. Cheong and S. Hamanaka. Methodology for Impact Assessment of Free Trade Agreements. Asian Development Bank, Manila, 2010

[8] Tambunan, T, Is ASEAN Still Relevant in the Era of the ASEAN-China FTA?.Kadin Indonesia-Jetro Paper, Jakarta, 2005.

[9] Tongzon, J., ASEAN-China Free Trade Area: A Bane or Boon for ASEAN Countries? World Economy 28(2), 2005, 191-210.

[10] UNCTAD, UNCTADStat database online., 2012 http://unctadstat.unctad.org/ReportFolders/reportFolders.aspx?sCS_referer=\&sCS_ChosenLang=en

[11] Roland-Holst, D. and Weiss, J., ASEAN and China: Export Rivals or Partners in Regional Growth?.World Economy 27(8), 2004, 1255-1274.

[12] Wai-Heng Loke, East Asia and Southeast Asia: Similarity in Trade Structures.Paper presentation at The Singapore Economic Review Conference (SERC), 6-8 August, 2009 